\title{
How many genes might underlie QTLs for growth and wood quality traits in Eucalyptus?
}

\author{
Carolina Sansaloni ${ }^{i *}$, César Petroli', Georgios Pappas², Orzenil Da Silva², Dario Grattapaglia ${ }^{3}$ \\ From IUFRO Tree Biotechnology Conference 2011: From Genomes to Integration and Delivery \\ Arraial d'Ajuda, Bahia, Brazil. 26 June - 2 July 2011
}

\section{Background}

QTL mapping is an unbiased approach where the phenotype reveals the location of regulatory genes or genomic regions affecting the trait of interest. The development of transferable molecular markers and the increased use of multiple pedigrees for QTL mapping have allowed comparative analysis of QTLs across independent studies thus providing validation data. Such QTL positional information, together with the availability of annotated genome sequences, now promises to identify strong candidate genes for a number of traits [1]. As large pedigrees become available and higher resolution mapping with SNPs, DArT and genotype-by-sequencing technologies becomes routine in forest trees, QTL positional information could be an alternative to the current approaches that rely on tentative candidate genes for association genetics studies. Among the several traits for which QTLs have been mapped in forest trees those that display higher heritability, such as wood chemical composition, are more likely to involve candidate genes of stronger effect although recent association studies show that even such genes explain very small proportion of the variation [2]. In this study we used a high-resolution map with over 2,000 Diversity Arrays Technology (DArT) markers to carry out an initial assessment of the number of annotated gene models in the reference genome sequence of Eucalyptus that putatively co-locate with QTLs for growth and wood quality traits.

\section{Methods}

A QTL mapping study was carried out with a clonally replicated segregating population of 171 F1 individuals

\footnotetext{
* Correspondence: carols@cenargen.embrapa.br

'EMBRAPA Genetic Resources and Biotechnology - EPqB Final W5 Norte 70770-917 Brazilia DF and Dep. Cell Biology, Universidade de Brazilia - UnB, Brazil

Full list of author information is available at the end of the article
}

derived from an E. grandis x E. urophylla cross. Individuals were genotyped with the Eucalyptus DArT microarray described earlier [3]. The DArT marker data were combined with 222 microsatellites and a linkage map for each parent was constructed using JoinMap 3.0 [4]. Six traits were measured: height growth (HG), circumference at breast height (CBH); wood specific gravity (WSG); cellulose pulp yield (\%PULP); Total Lignin (TL); syringyl/guaiacyl ratio (S/G). QTL mapping was carried out using QTL Cartographer [5] on the two parental maps separately at $1 \mathrm{cM}$ intervals. Empirical threshold significance levels for QTL detection were determined by 1,000 permutations considering a significance level of $5 \%$. All the segregating DArT and microsatellite markers were mapped onto the 11 pseudo-molecules of the Eucalyptus grandis draft genome sequence covering $609 \mathrm{Mbp}$.

\section{Results}

QTL analyses were carried out using framework genetic linkage maps with high likelihood support for order. The maternal map had 825 markers (684 DArTs + 141 SSR) and the paternal map 511 markers (410 DArTs + 101 SSR). A total of 16 QTLs in E. grandis and 14 in $E$. urophylla were detected influencing growth and wood quality traits. High and significant positive phenotypic correlations were found between $\mathrm{CBH}$ and $\mathrm{HG}$, TL and S/G, and S/G and \%PULP. In the maternal E. grandis map, five QTLs were identified for TL (Linkage groups (LG) 1, 3, 4, 5 and 8), two QTLs for \%PULP (LG 4 and 5), three for S/G (LG 1, 5 and 8), WSG (LG 6, 8 and 10) and HG (LG 1, 2 and 6). In the E. urophylla paternal map we detected three QTLs for \%PULP (LG 1, 4 and 9), three for HG (LG7, 8 and 10), three for TL (LG3, 4 and 8), two for CBH (LG7 and 10), two for S/G (LG 8 and 9), and one for WSG (LG 8). More than two QTLs were clustered on LG 4, 5 and 8 in E. grandis and 
on LG 4, 8 and 9 in E. urophylla suggesting interesting genomic regions to look for candidate genes to be tested in association mapping. Several of these QTLs were syntenic to QTLs found in other studies [6,7] providing some indirect support for their validity. The sequences of DArT and microsatellite markers bracketing QTLs were used to extract the gene models from the Eucalyptus reference genome. A total of 7,125 predicted gene models are found across all maternal QTLs, with an average of 445 genes per QTL. For the paternal QTLs 5,076 gene models exist, with an average of 362 genes per QTL.

\section{Conclusions}

As in many other QTL mapping studies in Eucalyptus [6-8] we have identified several QTLs that control a modest proportion of the phenotypic variation for a number of economically important traits. In this first assessment of putative candidate genes co-locating with these QTLs we found thousands of annotated gene models, hundreds of which could be tentatively suggested as being involved in trait variation. Notwithstanding the low mapping resolution provided by the small progeny, this preliminary study shows that tens or hundreds of genes will likely be always found underlying QTLs for such complex traits. Testing and validation of such large numbers of genes will require a gigantic effort. Furthermore a large proportion of the phenotypic variation remains unexplained by the few QTLs mapped. It is therefore questionable from the applied stand point how much useful information this approach will effectively provide for the advancement of association genetics and, for that matter, of breeding practice.

\section{Acknowledgments}

This work was supported by the Brazilian Ministry of Science and Technology through CNPq grant 577047/2008-6 and FAP-DF Grant NEXTREE 193.000.570/2009 and EMBRAPA Macroprogram 2 project grant 02.07.01.004

\section{Author details}

${ }^{1}$ EMBRAPA Genetic Resources and Biotechnology - EPqB Final W5 Norte 70770-917 Brazilia DF and Dep. Cell Biology, Universidade de Brazilia - UnB, Brazil. 'EMBRAPA Genetic Resources and Biotechnology - EPqB Final W5 Norte 70770-917 Brazilia DF, Brazil. 'EMBRAPA Genetic Resources and Biotechnology - Estação Parque Biológico, 70770-910, Brazilia, DF and Genomic Sciences Program - Universidade Católica de Brasília - Brazilia, Brazil.

Published: 13 September 2011

\section{References}

1. Price AH: Believe it or not, QTLs are accurate! Trends Plant Sci 2006, 11(5):213-216.

2. Wegrzyn JL, Eckert AJ, Choi M, Lee JM, Stanton BJ, Sykes R, Davis MF, Tsai CJ, Neale DB: Association genetics of traits controlling lignin and cellulose biosynthesis in black cottonwood (Populus trichocarpa, Salicaceae) secondary xylem. New Phytol 2010, 188(2):515-532.

3. Sansaloni CP, Petroli CD, Carling J, Hudson CJ, Steane DA, Myburg AA, Grattapaglia D, Vaillancourt RE, Kilian A: A high-density Diversity Arrays
Technology (DArT) microarray for genome-wide genotyping in Eucalyptus. Plant Methods 2010, 6:16.

4. Stam P: Construction of Integrated Genetic-Linkage Maps by Means of a New Computer Package - Joinmap. Plant Journal 1993, 3(5):739-744.

5. Wang S, Basten CJ, Zeng Z-B: Windows QTL Cartographer 2.5. North Carolina State University, Raleigh, NC: Department of Statistics; 2011.

6. Thumma BR, Southerton SG, Bell JC, Owen JV, Henery ML, Moran GF: Quantitative trait locus (QTL) analysis of wood quality traits in. Eucalyptus nitens. Tree Genetics \& Genomes 2010, 6(2):305-317.

7. Freeman JS, Whittock SP, Potts BM, Vaillancourt RE: QTL influencing growth and wood properties in Eucalyptus globulus. Tree Genetics \& Genomes 2009, 5(4):713-722.

8. Grattapaglia D, Kirst M: Eucalyptus applied genomics: from gene sequences to breeding tools. New Phytologist 2008, 179(4):911-929.

doi:10.1186/1753-6561-5-S7-P37

Cite this article as: Sansaloni et al: How many genes might underlie QTLs for growth and wood quality traits in Eucalyptus? BMC Proceedings 2011 5(Suppl 7):P37.

\section{Submit your next manuscript to BioMed Central and take full advantage of:}

- Convenient online submission

- Thorough peer review

- No space constraints or color figure charges

- Immediate publication on acceptance

- Inclusion in PubMed, CAS, Scopus and Google Scholar

- Research which is freely available for redistribution 